\title{
Re-viewing Studies on Africa, \#Black Lives Matter, and Envisioning the Future of African Studies
}

\author{
Akosua Adomako Ampofo
}

Editors' note: An earlier version of this article was presented as the ASR Distinguished Lecture at the 58th annual meeting of the African Studies Association, November 2015, San Diego, California.

\begin{abstract}
This article considers what African Studies needs to look like in order for it to retain its disciplinary relevance for the next generation and in the larger context of the Black Lives movement globally. It asks questions about where we have come from in terms of race consciousness in our discipline and why this issue matters today. It begins by tracing the development of African Studies' epistemic journey, and follows this with an examination of the recent Black student movements in South Africa and the U.S. It concludes by suggesting where we should be going.
\end{abstract}

Résumé: Cet article traite ce que les études africaines doit ressembler afin de conserver sa pertinence disciplinaire pour la prochaine génération et dans le cadre plus large du mouvement "Black Lives Matter" au niveau mondial. Il pose des questions sur où l'on vient en termes de conscience de la race dans notre discipline et pourquoi ce sujet est important encore aujourd'hui. Il commence en retraçant le

African Studies Review, Volume 59, Number 2 (September 2016), pp. 7-29

Akosua Adomako Ampofo is a professor of African and Gender Studies at the University of Ghana, where she was the founding director of the Centre for Gender Studies and Advocacy. In 2015-16 she was a Fulbright Scholar-in-Residence at Concordia University, Irvine, California. Adomako Ampofo's work addresses African knowledge systems, higher education, identity politics, gender-based violence, women's work, masculinities, and gender representations in popular culture. She is founding vice-president of the African Studies Association of Africa (ASAA), co-editor of the "Critical Investigations into Humanitarianism in Africa" blog, a Fellow of the Ghana Academy of Arts and Sciences, and an honorary member of the Human Sciences Research Council of South Africa. E-mail: aadomako@ug.edu.gh 
développement du voyage épistémique des Études Africaines et suit cela avec une analyse des mouvements récents des étudiants noirs en L'Afrique du Sud et les États-Unis. Il conclut en suggérant où nous devrions aller.

Keywords: African-centered knowledge; African Studies; Afrofutures; Black Lives Matter; Rhodes Must Fall; decolonization; higher education; student movements; social media; African diaspora

Critical reflection, therefore, involves not only rethinking the prospects of pan-African unity under conditions of global coloniality, but also understanding the constitution of the present, taking stock of the sacrifices made by Africans in their struggle to defeat global imperial designs as well as understanding the invisible and visible colonial matrices of power that continue to reproduce a particular form of African subjectivity that is characterized by "deficits" and "lacks."

—Sabelo Ndlovu-Gatsheni (2014)

\section{Re-viewing Studies on Africa and Envisioning Our Future}

About a year ago, when I was invited to present the ASR Distinguished Lecture at the annual meeting of the African Studies Association, all I was certain of was that I wanted to be able to make some hopeful utterances for our tomorrows. So I reflected on the journey we Africanists have traveled and pondered my expectations for the future of my profession; in other words, I did some stocktaking. Many important reviews on African Studies as a discipline and of programs have been presented, including by ASA members such as Jane Guyer (1996) and Paul Zeleza (1997), and more recently Toyin Falola and Christian Jennings (2002). As early as 1964 Melville Herskovits assessed the development of "Africanist" Studies in Europe and America; Tejumola Olaniyan and James Sweet (2010) reviewed the African diaspora and the disciplines; and as recently as 2016 James Gordon and Emmanuel Acheampong provided a very useful overview of the history and development of African Studies around the world. A particular benefit of Gordon and Acheampong's work is that it documents which institutions are doing what, including offering a list of centers and institutes around the world. My intention is to re-view, to take another look, at what African Studies might mean today. What does it mean for the survival of our DNA, as Africanists, especially among millennials, and at a time of Afro-revivalism as well as a heightened onslaught on Black bodies globally. ${ }^{1}$ I am particularly interested in links between resistance and enabling discourses on the continent and the diaspora and what this promises for African Studies. Essentially, I seek to bring into one conversation the following: (1) a narrative of "where we have come from"; (2) a brief account of attacks on Black lives and thought and the responses to these, particularly the recent 
"Black Lives Matter" (BLM) and "Rhodes Must Fall" (RMF) movements on U.S. and South African university campuses, respectively; and (3) what, in my view, this should signify for African Studies (i.e., a suggestion of "where we should be going").

\section{The Africanist: The Survival of Our DNA}

Scholars inside and outside the academy may not have the power and influence of Nelson (Madiba) Mandela or Beyoncé Knowles. Unless we are active bloggers or have some other high-hit social media presence, our work, even of the best known among us, may reach a few thousand readers. With multiple new editions of our most popular books, the most prolific among us may reach an audience of a few thousand. Many of us won't come close. According to Google Scholar, the 1989 version of the book Molecular Cloning by Sambrook et al., one of its most cited works, had been referred to 175,667 times as of April 2016, up by 526 citations since I first checked in late

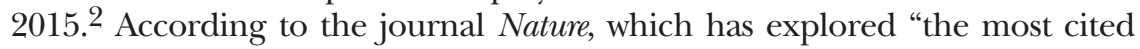
research of all time," it takes a "staggering 12,119 citations to rank in the top one hundred and many of the world's most famous papers do not make the cut" (Van Noorden, Maher, \& Nuzzo 2014). (I will address the politics of publishing and knowledge gatekeeping soon, so please bear with me). According to Nature, the most cited article is a 1951 paper by Lowry et al. in the Journal of Biological Chemistry titled "Protein measurement with the folin phenol reagent." 3 Even in that more popular domain of scholarly output, documentary films, the most viewed, according to one website, is Food Inc, a 2008 film that examines food and eating cultures and the agriculture and food industry as a whole. It has had a little over six hundred thousand views. ${ }^{4}$

In contrast, consider the views that the following music videos have received on YouTube as of April 2016. "Gangham Style," first uploaded to the Internet in July 2012, had received 2.56 billion views. 5 Even Beyoncé Knowles doesn't come close; her most-watched YouTube video, "Young Forever/Halo," first posted in September 2014, had just under 20.5 million hits. ${ }^{6}$ U-Media Films' Azonto, one of Ghana's most popular dance videos, first offered on YouTube in October 2011, had received 23.3 million hits, ${ }^{7}$ and the extremely popular video "Oliver Twist" of the top Nigerian musician D'banj, first posted on YouTube in March 2012, had received 38.2 million hits. ${ }^{8}$ The most popular videos of Anne Kansiime, a Ugandan comedian, receive around a half million viewings. We can of course argue that the South and Southeast Asian market gives "Gangham Style" an unfair advantage, but my point, simply, is that popular culture icons would seem to have a much longer reach than we do.

I say popular culture icons "would seem" to have a longer reach, because those of us in the academy do have wide-reaching epistemic power. Professors are the experts; we determine what should be known, and how that knowledge should be collected and articulated. We define constructs and deconstruct others. Our reach extends into the corridors of political 
spaces, and we influence policy, or at least political thinking and rhetoric. Year after year young people enter our classrooms; they hear us, understand us, believe and trust us. Our students take our work and spice up their virtual spaces with our wisdom. They go into the field, at home or abroad, and they borrow our lenses as they view and share their views on society. Many from the global North join the study-abroad train or humanitarianism business, where they either perpetuate or destabilize stereotypes. ${ }^{9}$ They too become experts. Some of us are ourselves public intellectuals, constantly invited to speak in churches and mosques, high schools and professional gatherings, on radio and television, or we muse on our blogs and other social media sites. Our explanations of the material world and its problems, and how these should be understood (or not), and fixed, affect people's everyday lives in far-reaching ways that cannot be measured. We may even reach several million who have never read a book or entered a classroom. A particularly potent example is Beyoncé Knowles's sampling of the Nigerian writer Chimamanda Adichie's work in her 2013 Song "Flawless." "Flawless" consists of two parts- "Bow Down" and "Flawless," divided by a speech titled "We should all be feminists" delivered by Adichie at a Tedx Euston conference. Upon its release, "Flawless" was received positively by music critics who were particularly impressed with Knowles's use of Adichie's sample and who widely discussed and acclaimed its lyrics. Adichie herself has noted, "I'm happy that my thirteen-year-old niece calls herself a feministnot because I made the speech, but because of Beyoncé. Having attained the status of 'cool' to my niece is wonderful."10

Foucault is perhaps more responsible than most scholars for popularizing the notion of epistemic power. I believe that even the pessimists and realists among us would agree that we have epistemic power. So if we agree that this is true, then what are our (moral) obligations to ensure the survival of the African-centered knowledge production and dissemination project - to one another in the fraternity, to our social and cultural communities, and especially to the next generation who will ensure the survival of our profession, and to those who may seem removed from our daily realities?

Crain Soudien, in the foreword to a collection of papers in a volume on Africa-centered knowledge (Cooper \& Morrell 2014), asserts that we have two obligations: (1) to ensure the democratization of knowledge, and (2) to constantly nurture a self-awareness of the impact of our work beyond our social, religious, ethnic, national, and cultural contexts. The obligation here, he argues, is to explain ourselves to one another, and provide what he terms "civilizational procedures for how to deal with ourselves in each other's presence" (2014:xv).

In the next section I provide a very brief narrative of the epistemic journey of African Studies, including the content covered in our association's journal, the African Studies Review. I then go on to situate what I refer to as "the onslaught on Black and Brown bodies and thought," and youth responses to this. I conclude with some comments on what these youth perspectives portend for "Afrofutures."11 


\title{
Our Epistemic Journey
}

The development of African Studies on the continent, and Black Studies in the diaspora, was concerned with refuting notions of Black subjectivity, that lacking "other," that constituted Euro-American constructions. The leaders of liberation, independence, and civil rights movements recognized that the modern university was a European construct: hence the importance of an African-centered approach to knowledge production to advance panAfricanism and decolonization. Kwame Nkrumah's charge to the fellows of the Institute of African Studies, established in 1961 at the University of Ghana, is instructive. At the formal opening in 1963 Nkrumah exhorted,

\begin{abstract}
One essential function of this Institute must surely be to study the history, culture and institutions, languages and arts of Ghana and of Africa in new African-centred ways-in entire freedom from the propositions and presuppositions of the colonial epoch, and from the distortions of those Professors and Lecturers who continue to make European studies of Africa the basis of this new assessment. By the work of this Institute, we must re-assess and assert the glories and achievements of our African past and inspire our generation, and succeeding generations, with a vision of a better future.
\end{abstract}

Nkrumah went on to exhort the fellows of the institute to extend their focus beyond the continent and to include the study of the African diaspora in their work.

\begin{abstract}
But you should not stop here. Your work must also include a study of the origins and culture of peoples of African descent in the Americas and the Caribbean, and you should seek to maintain close relations with their scholars so that there may be cross fertilisation between Africa and those who have their roots in the African past.
\end{abstract}

And when Ghana gained her independence in 1957, at a time when Black people in the Americas were in the throes of the civil rights movement, he, and other leaders on the continent, insisted that Ghana's independence was meaningless without freedoms for Africans in the diaspora. Similar institutes with a pan-African and decolonial agenda were established at the Universities of Ibadan and Nigeria in 1962 and 1963, respectively, and Addis Ababa University in Ethiopia in 1963. The Centre for African Studies at the University of Cape Town, the oldest on the continent, was, however, set up with a colonial agenda to grapple with the "native question" so as to colonize successfully. ${ }^{12}$

W.E.B. Du Bois died, aged 95, on August 27, 1963, in Accra, Ghana, a day before the August 28, 1963, March on Washington at which Martin Luther King gave his "I Have a Dream" speech. Not long before, having been given Ghanaian citizenship, Du Bois declared, "I have returned so that my remains may mingle with the dust of the forefathers." He continued, 
"Now my life will flow on in the vigorous young stream of Ghanaian life which lifts the African personality to its proper place among men. And I shall not have lived and worked in vain" (quoted in Alexander 2015:130). Du Bois's efforts to establish the field of Black Studies was recorded as early as 1941 when he spoke at the Annual Conference of Presidents of Negro Land Grant Colleges (Warrant 1941). He was viewed by many African intellectuals as the father of modern pan-Africanism, and his role in establishing the panAfrican congresses, and his campaigns to end colonialism, made him an inspiration to many African leaders (Alexander 2015; see also New African Magazine 2015).

Though Du Bois's life in Ghana was short, barely two years, it was very productive. He worked with Nkrumah on the Encyclopedia Africana, and this and other work drew radical African American intellectuals and artists to Ghana and other parts of Africa. They included Julian Mayfield, an activist and writer who became a speechwriter and aide to President Nkrumah; the writer Maya Angelou, who taught at the University of Ghana; and Bill Sutherland, who married the famous Ghanaian playwright and artist Afua Sutherland. And of course, Du Bois's second wife, Shirley Graham Du Bois, accompanied him to Ghana and was instrumental in the establishment of the Ghana Broadcasting Corporation.

This brief narrative allows us to recognize the important role played by Blacks in the U.S. in the development of critical African (Black) Studies. In his presidential address at the 2014 ASA meetings in Indianapolis, James Pritchett reminded us that long before the establishment of formal programs in African Studies at universities and colleges, indeed by the end of the Civil War, the Negro Upliftment projects had a pan-African agenda deeply embedded in them. ${ }^{13}$ When Du Bois asked, in the Souls of Black Folk (1903), what it felt like for a Black person to be a "problem," he was articulating the potent need to forge a meaningful identity at a time when Blacks in the U.S. had become the "Negro problem." The racial uplift project was the response of educated, middle-class Black leaders, who felt they had a major responsibility to "lift up" Blacks in the face of the on-going Jim Crow onslaught on their lives, identities, and personhood. Their efforts to provide education that would inspire and "lift up" led them to pursue studies of the history and culture of the African continent. Academics such as Du Bois, as well as clergy and community leaders, paid attention to issues that concerned the continent and linked the ways in which, in today's parlance, "Black Lives Mattered" across space. ${ }^{14}$ By a "Black Lives" approach I simply mean one that specifically addresses issues of race and oppression-what Sabelo Ndlovu-Gatsheni (2014) refers to as "complex colonial matrices of power" (2014:121) —and specifically links the experiences of people of African descent globally. This attention to linking the experiences of continental Africans and Blacks in the U.S. was at least partly responsible for Kwame Nkrumah's studying at Lincoln University, a Historically Black University.

Subsequently African Studies programs at the Research1 Universitiesas they have come to be named-such as Boston, Indiana, Northwestern, 
and the University of Florida were a product of the Cold War and the particular agenda at the time, namely, securing U.S. interests on the continent. This should be viewed within the wider context of area studies in the U.S., which had its roots in national security interests. After World War II-which by the way, wasn't the war of most of the world-both so-called liberals and conservatives in the U.S. were concerned about the ability of the U.S. to respond effectively to perceived threats from the Soviet Union and China, as well as a potential domino effect of liberation movements on the African continent. The National Defense Education Act of 1958 spurred the teaching of less commonly taught languages, and the Department of Education's Title VI framework referenced maintaining the "security, stability and economic vitality of the United States" as the central motivation for supporting area studies. The guiding principle behind these programs was that area studies would yield practical knowledge that could be used to make better policy. ${ }^{15}$ The Ford Foundation, the Rockefeller Foundation, and the Carnegie Corporation of New York came to an agreement to address this knowledge deficit and invest in international studies, including African Studies (Gordon \& Acheampong 2016; Pritchett 2014). In the intervening years all three have funded many programs that support African Studies in the U.S. and higher education more broadly on the continent-most recently, for example, Carnegie's Next Generation program. ${ }^{16}$

In the 1920s both the Carnegie Corporation and the Rockefeller Foundation gave modest grants $(\$ 25,000$ over five years) to the Association for the Study of Negro Life and History, whose work included the study of Africans on the continent (Chellenor 2002). From the 1950s, Historically Black Colleges and Universities (HBCUs) promoted African Studies; Howard, Atlanta, and Fisk, for example, offered courses on "Negro history" that included African history. In 1953 Howard, following the awarding of a Ford Foundation grant, was the first HBCU to establish a formal African Studies program (Challenor 2002). Indeed, Howard remains one of the few universities with a fully-fledged department, and as far as I am aware, it was also the first university to offer a Ph.D. in African Studies.

Today there are more than fifteen Ph.D.-degree-granting institutions in the field of Black Studies and several more in the field of African Studies in the U.S. According to the Institute of Education Statistics, African Studies is "a program that focuses on the history, society, politics, culture, and economics of one or more of the peoples of the African Continent, usually with an emphasis on Africa south of the Sahara, and including the African diasporas overseas." 17 Initially African and Black Studies were not bifurcated at HBCUs the way they are today, although the former focused on the continental experience with an "upliftment" agenda for Blacks in the U.S. and the latter focused on challenging racism in the U.S. In their report on a 2013 survey of Black Studies, Abdul Alkalimat and his colleagues at the University of Illinois noted that the academic specialty was established as "a direct confrontation with the institutionalized white racism that controlled higher education." 18 According to the report, of the total number 
of institutions surveyed (1,777), 76 percent have some form of Black Studies, 20 percent with formal units and 56 percent without units but with a course or courses. Public colleges and universities are more likely to have Black Studies: 91 percent, as opposed to 77 percent of private institutions. The report recommends a number of priorities for African American Studies at the graduate level, including "global connections and diaspora dialogues." However, neither African nor African American nor Black Studies make it onto the list of the top two hundred masters or doctoral degrees in the U.S., according to the MyPlan.com website, which helps students and professionals in career planning. Further, the early concrete connections between the lives of Africans on the continent and in the U.S. in the study of the Black experience have all but disappeared-students either focus on one or the other. This is true of African Studies on the continent as well, where a focus on the diaspora experience is limited.

Gordon and Acheampong (2016) list twenty centers and institutes in Africa that provide training in African Studies, including three offering a B.A. degree. Most of the newer ones focus on the political and economic development of Africa, a.k.a "contemporary problems." As I see it, a major challenge to retaining an anticolonial agenda (or building one in the case of postindependence institutes and centers) is the notion held by many administrators and faculty that everyone in an African university does African Studies. At the Institute of African Studies at the University of Ghana this assumption has been the focus of an ever-recurring discussion requiring a justification of the discipline.

While African students who attended colonial schools in Africa learned more about European "empires" than about Africa, African Studies institutions that were established in Europe firmly followed the colonial agendato know and conquer Africa, as evidenced by their content and the research questions they asked. African knowers and philosophers were generally not included in the sources or as teachers, for they were the subject, the "other." This is what Nkrumah referred to in his 1963 speech as "European Studies of Africa." The School of African and Oriental Studies (SOAS) at the University of London is perhaps the most well known. It was established in 1916, after the so-called Oriental Schools had already been established in Berlin, Paris, and Petrograd. Later, in the 1940s and 1950s, more institutes were set up in the former Soviet Union to counterbalance Western Europe's dominance in the field: the Department of African Studies at Saint Petersburg University (1944), the Institute of Asian and African Studies at the Lomonosov Moscow State University (1956), and the Institute of African Studies at the Russian Academy of Sciences (1959). The Centre d'Etudes Africaines at the Université Montesquieu in Bordeaux was established in 1957 (Gordon \& Acheampong 2016). Gordon and Acheampong (2016) list twenty-eight centers, departments, or institutes in Europe. The terrain is very mixed, of course, but today African Studies in Europe, as in the U.S. and Africa, very much pays attention to contemporary issues. Although created in very different geopolitical moments, the U.S. African Studies 
Association (ASA) and the Africa-Europe Group for Interdisciplinary Studies (AEGIS), established in 1957 and 1991, respectively, both seek to "understand" Africa. ${ }^{19}$ No specific mention of African-centered knowledge or links to the diaspora are mentioned in their mission statements. However, the African Studies Association of Africa (ASAA), established in 2013, does state clearly that its mission is "to promote Africa's own specific contributions to the advancement of knowledge about the peoples and cultures of Africa and the Diaspora." ${ }^{20}$ Space will not permit me to pay attention to African Studies in Asia and the Middle East; however, suffice it to say that with the possible exception of India, most centers and institutes were established after the Cold War and have a very policy-focused orientation. A late entrant to the modern cultural export game, China, has "gifted" Confucius centers and institutes to universities across Africa, including the University of Ghana, my home. And our universities have accepted these uncritically, with no discussion of new forms of cultural dominance. At the same time, political correctness has not attained the status of self-censoring guard in China that it has in the global North, and explicitly racist representations find comfortable homes. ${ }^{21}$

I would like to conclude this section by focusing on the output of this journal, the African Studies Review. The mission of ASR, the ASA's principal scholarly journal, is to "publish the highest quality articles . . . of interest to the interdisciplinary audience of ASA members." Obviously many important papers are presented at the ASA annual meetings that never end up in $A S R$, and the articles are not all produced by ASA members; however, they provide some indication of what our interests are. ${ }^{22}$ My former teaching assistant and a Ph.D. student at IAS created a database of all ASR articles between 1965 and September 2015 (see appendix). I analyzed a total of 1,226 articles by the sex of the author(s), country of institutional location, institution, and subject. ${ }^{23}$ I sought to glean how many articles directly addressed issues pertinent to the broader question of what we might call Black lives, the African diaspora, or pan-Africanism. ${ }^{24}$ It is important to explain that this database should be considered as suggestive rather than as an "objective" collection, bearing in mind the following limitation: I relied principally on titles and key words to assign articles to subject categories. Obviously there will be much that I missed from this limited approach; for example, an article on Structural Adjustment might pay attention to the ways in which the Bretton Woods institutions delegitimize African knowledge even though valorization of African knowledge systems is not its main focus.

By way of background demographic information: female authorship increased from 12.4 percent in the 1960 s to 37.8 percent in the period 2006-15. While authorship by African-based scholars has sea-sawed $(13.6 \%$ in the $1960 \mathrm{~s}, 22 \%$ in the 1970 s, down to $13 \%$ in the $1980 \mathrm{~s}$, and $13.4 \%$ in the period 2006-15), authorship by scholars based in Europe has increased steadily (from $1 \%$ in the $1960 \mathrm{~s}$, to $3 \%$ in the $1970 \mathrm{~s}, 19.5 \%$ in the $1990 \mathrm{~s}$, and $24 \%$ in the recent decade). The proportion of authors based in the U.S. and 
Canada has declined from 71 percent in the 1960s to just under 60 percent. This is probably a function of the increasing membership of scholars from the continent. There was one author based in the Caribbean.

In terms of content, over the period, 1.3 percent of articles directly addressed what I would consider the topics of Black lives, the African diaspora, or pan-Africanism. These articles either discuss the Black experience outside of and across the continent, or they provide discussions of the links between the Black experience across geopolitical spaces, including what we might refer to as "upliftment" activism. Given the relatively small percentage of articles focused on the diaspora overall, I would conclude that the interest of members of the ASA and ASR authors remains focused on issues pertinent to the experiences of Africans on the continent. Indeed, this was the reason that I myself joined the ASA in 1995. However, I believe the times we live in call for us to consider paying more attention to the politics of Blackness and the connected experiences of people on the continent and in the diaspora.

\section{Black Bodies, the "Rhodes Must Fall" and "Black Lives Matter" Movements, and African Studies}

During the first half of 2016 I was at a conference at a university in the U.S. On the first day the dean of the division hosting the conference welcomed, among others, participants from the "U.K., Canada, India, and Africa." There were two of us "from Africa," both from Ghana. I am sure anyone from the continent has many stories of similar experiences. The "Africa-isa-country" view of the continent persists even among academics. While in the U.S. as a Fulbright Scholar this year I taught a class titled "Culture and Self" that included a viewing of the movie Skin (2008), about a young girl, Sandra, who would have been considered "coloured" by the phenotypical race standards of South Africa at the time. Sandra was born to white parents. In their reflection responses to the film several students in my class referred to Sandra as the "African American" girl. Race matters, and the Black experience, albeit context specific, contains sufficient similarities to retain salience. This is true whether one is dealing with questions of migration, employment, police attitudes, or knowledge production, all sites of the "othering" of Black bodies.

The academy, for one, both on the continent and in the diaspora, privileges Euro-centered knowledge and methods, and the privileging of non-African voices persists. In his essay collection titled You're Not a Country, Africa (2011) Pius Adesanmi, a Nigerian scholar of literature and French, presents an interesting piece titled "Sarah Baartman, Invisible!", a fictitious letter written by Sarah Baartman to Sandra Gilbert and Susan Gubar, the editors of the Norton Anthology of Literature by Women (2007). ${ }^{25}$ Adesanmi (via Baartman) laments the "excision of African theories and theorists" (2011:109) from this 2,452-page, two-volume collection. Another example of such exclusion is the 2013 Oxford Handbook of Modern African History, 
which does not have a single African author among the twenty-six authors. It is difficult to believe that the editors, John Parker and Richard Reid, could not find any African historians competent to write on their continent. A final example should suffice. The Women, Gender, and Sexuality Studies' 2015-16 speaker series at Yale University titled "Gender and Political Economy in Africa" included four speakers, three of whom were white women from the U.S., while the fourth was a non-Black South African. I am not suggesting that only Africans and their descendants should embody knowledge on Africa. But that a series on Africa could not find at least half of the speakers from Africa I find unacceptable, especially given that there are so many Africans in the American academy and also that Yale University has the resources to fly in a speaker from anywhere on the globe. The \#WherearetheAfricans Twitter feed emerged to reflect this "excision" (Adesanmi 2011). 26

As we know all too well, not all voices have the same power-where we speak, and the authority of our voices don't have equal reach, and hence impact our lives differentially. Some voices are marginalized by the way the academy is structured in different places around the globe, exemplified most sharply perhaps by the so-called impact factor syndrome. Since American and European journals are prized, African scholars both on the continent and in the diaspora seek to publish in these "high impact" journals to gain tenure, and they have to legitimize their own knowledge by referencing European and American authors. And as African and other Black scholars chase these journals, the continental and other purportedly less prestigious Black ones don't receive the submissions that will promote them; scholars on the continent are deprived of the research, the journals stagnate, African experiences and perspectives are deprioritized, and the cycle continues. The same can be said of other aspects of the scholarly project-research priorities and projects, grant sources, professional associations, teaching methodologies, faculty hiring and promotions. Interestingly, the University of Ghana recently announced that it would establish a division of European Studies within the Centre for Social Policy Studies, "to broaden the frontiers of research and learning." Vice-Chancellor Ernest Aryeetey is reported to have noted that "the Centre would provide avenues to study European politics, law, history . . . [and advise] government about its impact on the economy for possible solutions." 27 One hopes that this is our initiative and that it will be European studies that helps us understand the "Other" with a view to dismantling, not merely responding to, Euroecentric geopolitics.

Enter the "Rhodes Must Fall" (RMF) and "Black Lives Matter" protests that spread across university campuses in South Africa and the U.S. in 2015. While these are very specific contexts, and some may argue that their experiences are not translatable into majority African nations, I would disagree. A majority African population does not imply a decolonized education, and many Africans have merely submitted themselves quietly to conditions of subordination, even as they are opposed to them (see Ndlovu-Gatsheni 2014). Both movements illustrate the extent to which today's Black (and 
some white) students expect the university to become a decolonized space, and what they are willing to do to see this happen.

The cyber world is replete with accounts of both movements, and both have been criticized by some as being the mere tantrums of privileged middle-class Black youth. My own limited experience with some students at the Universities of Cape Town in South Africa and Yale University in the U.S. suggests that although there were elements of this, as with all movements, the call for "transformation" was genuine and broad-based. From August to September 2014 I was a Mellon Fellow at the Centre for African Studies at the University of Cape Town (UCT) and witnessed the beginnings of the fusing of anger and frustration into action. In diverse student meetings I attended as well as informal gatherings Black students expressed frustration with the content of their education, from texts to methodologies. One student complained that what he learned in class from his economics lecturer was far removed from his own reality and that he could teach his lecturer a thing or two about economic survival in poor Black communities. Another, a graduate student, narrated his struggle to get his lecturer to agree to his writing his honors thesis on an African playwright rather than on one of the Europeans offered for consideration; his lecturer's initial response was that no literature existed on that African playwright. Others voiced anger at the structure of the university system that was not designed, they felt, to take account of the cultural diversity of students, specifically the experiences of Black students. And many expressed frustration, pain, and anger that the statue of Cecil Rhodes still greeted them at the pinnacle of the university despite multiple requests since 1994 for its removal.

Cecil John Rhodes was a British businessman, mining magnate, and South African politician who served as prime minister of the Cape Colony from 1890 to 1896. Born in England on July 5, 1853, he moved to South Africa when he was only seventeen. He was a committed British imperialist, and his views on race have led contemporary critics to label him as an "architect of apartheid" (Rothberg 1988) and a white supremacist (see also Magubane 1996, Attiah 2016). At the time of my visit there was a sign beneath the statue acknowledging the requests for its removal but noting that the university felt it was a historical feature that needed to be retained. However, on April 9, 2015, following a UCT Council vote the previous night, the statue was removed. The campaign to remove it also led to the wider RMF movement to decolonize and transform education across South Africa by hiring more African faculty, Africanizing the curriculum, and increasing access for African students. ${ }^{28}$ Campaigns and protests followed at North-West, Witwatersrand, Stellenbosch, and Rhodes Universities, and the Universities of the Free State and Pretoria. During my fellowship at UCT in 2014 I workshopped a university-wide introductory course on African Studies taught at the University of Ghana. In response to the protests, in April 2015 UCT announced that it would be introducing Black Studies as part of its transformation project.

The "\#BLM" Twitter feed created in 2012 by three Black womenAlicia Garza, Patrisse Cullors, and Opal Tometi-provided the genesis for 
"Black Lives Matter" protests on U.S. campuses. The campaign was initiated after George Zimmerman (a white man) was acquitted for the shooting that resulted in the death of a teenager, Trayvon Martin, an African American teenager. BLM became nationally recognized for its street demonstrations following the deaths of several other African Americans, including the police shooting of Michael Brown in Ferguson, Missouri, the police choking of Eric Garner in New York City, and the death of Sandra Bland in police custody in Texas. The BLM website (http:/ /blacklivesmatter.com) declares that "BLM is a chapter-based national organization working for the validity of Black life. We are working to (re)build the Black liberation movement." The movement has gained global prominence with major protests in Berlin, London, and Paris in 2015 against police brutality.

In 2015 student protests also rocked more than one hundred U.S. university campuses. ${ }^{29}$ The issues ranged from demands that hostile environments and racist treatment of Black and other students of color be addressed, to calls that curriculums be decolonized and that links to slavery be acknowledged and corrected. For example, the Black Justice League at Princeton was particularly vocal in its demand for the removal of Woodrow Wilson's name from its School of Public and International Affairs. Wilson, a one-time president of Princeton and later of the U.S., is known to have opposed admitting Black students to the university in 1902, and was sympathetic or even had links to the Ku Klux Klan. ${ }^{30}$ The ten-member special committee set up to consider the demand voted to retain Wilson's name. However, students at Georgetown University succeeded in their campaign to change the names of two buildings named after university presidents who sold Jesuit-owned slaves to save the university from bankruptcy. For now, they are to be renamed Freedom Hall and Remembrance Hall. 31

The most prominent protests were those that took place at the University of Missouri (Mizzou) and at Yale. At Mizzou Jonathan Butler, a veteran of the Ferguson protests, went on a hunger strike to protest a series of racist incidents, including reports that feces were smeared in the form of a swastika in a dorm restroom. Students had long been unhappy about the administration's failure to respond to their concerns. A demonstration and a faculty walkout followed, and there were demands for the resignation of the Mizzou president, Tim Wolfe. When the largely African American football team boycotted games, a protest that would have cost the university millions of dollars if it had continued, it seemed the die was cast and and President Wolfe resigned. A series of new initiatives to address racial tensions on campus were instituted, including the hiring of a diversity, inclusion, and equity officer for the entire University of Missouri system.

There were also student protests at Ivy League schools such as Harvard, Dartmouth, Brown, and Yale, with the latter garnering the most attention. A series of events in late 2015 came to a head just before Thanksgiving. First some women students alleged that they were barred from attending 
a fraternity party which was admitting "white girls only." 32 Then swastikas were drawn across campus. Finally, an e-mail message from one administrator urging students to be "thoughtful" on Halloween and avoid insensitive costumes, including those that feature blackface, turbans, and mock Native American headdresses, was met with a response from another administrator suggesting that the e-mail exhorting students to be sensitive pandered to the culture of "coddling" young people and curtailed free speech. "Is there no room anymore for a child or young person to be a little bit obnoxious [,] . . . a little bit inappropriate or provocative or, yes, offensive?", Erika Christakis, the second administrator, responded in her own message. Students held a "March of Resilience" that garnered more than a thousand supporters and sent a detailed list of requests to President Peter Salovey, who acknowledged in a closeddoor meeting that the university had "failed" its minority students and that the students had made very mature and practical suggestions for the way forward. ${ }^{33}$ Among other things students requested that Yale actively seek to increase the numbers of Black faculty, address its historical ties to slavery, ensure that the campus is a safe space for minority students, and enrich its curriculum offerings by making them more diverse. A few weeks later Yale's president delivered on his promise to provide a concrete action plan that included a "strengthening of the academic enterprise" via a greater focus on "particularly intense study of Race, ethnicity, and other aspects of social identity." Yale also created new faculty positions and launched a five-year series of conferences on issues of race, gender, inequality, and inclusion.

\section{Foretelling our Futures}

This generation of young people and young scholars-including the descendants of those carried forcibly to North America, Europe and the Caribbean on boats, and the children of first- and second-generation immigrant parents-do not necessarily draw clear lines between the African experience on the continent and in the diaspora. They recognize that racebased police brutality knows no national origin. In 2015 we celebrated Black History Month at the Institute of African Studies, University of Ghana, in collaboration with the Africa World Documentary Film Festival sponsored by the University of Missouri, St. Louis. One of the films we showed was In His Own Home, a documentary about Kofi Adu Brempong, a Ghanaian Ph.D. student with mental health issues at the University of Florida who was shot several times in the head in his own home by police following a 911 call from a neighbor who heard him shouting. The predominantly Ghanaian audience "got it" quite clearly_that the police don't discriminate between presumed "good" and "bad" Blacks.

In a particularly eloquent speech given by the writer Adowa Badoe in 2012 at the University of Ghana, Badoe asks about the futures we will create from our stories. 
The real drive forward into the future is the story that is heard, known, held, and believed corporately. . . It begins with vision and hope. . . We need to understand the timelines of our being, seek the root and stem of our aspirations for our elders and children, the girls, the boys, the women, the men, and society at large. We need to talk about our attitudes, relationships, traditional cultures and also popular culture. We need to think of ourselves within our cultures and also against other cultures. We need to recreate the past, such that we can collectively experience it, while we discuss the present as observers and investigators of society. We must journey through history and what is currently news, and by our explorations, create futures as we see arise from the story. Then we must send the story into the future as a prophecy by the development of identifiable characters and the unmasking of our hopes.

Which hopes will we unmask, she asks? What stories will we tell? The student movements show us clearly the historical ties to slavery, colonialism, and racism that exist in the everyday lives of Black people, and in the cultures of the academy and knowledge production. The current flows of migration from North and West Africa are deeply tied to the erasure of Black lives. What is also clear, according to a briefing paper from the U.K. Race and Europe Network (Clark 2012), is that racist stereotypes about skin color are prevalent in Europe, and "anecdotal and country-specific evidence shows that people of African descent are consistently and disproportionately discriminated against" in everything from housing to employment. That includes policing: Blacks are six times more likely than whites to be stopped by Paris police, for example, and in a 2010 survey, sub-Saharan Africans in Spain were by far the most likely group to report having had police check their IDs in the street.

If we are to sustain our DNA as scholars of African Studies in the next generation we need to blur the lines between the experiences of people of Africa around the world and the attendant academic studies. ${ }^{34} \mathrm{We}$ must not, as Badoe also exhorted, continue to "embalm" the story, thereby nostalgically turning art into craft, "preservations of themes and enactments, connected by familiarity to a simplified history and function." She reminds us that early storytellers responded dynamically to the needs of their communities, to create a vision along with the processes needed to grow sustainable societies. Within the ASA our future should see a conscious reaching out to scholars in traditional "Black Studies" and African American Studies programs. For this to happen the ASA must intentionally sponsor papers and panels that respond to their interests and needs, professionally, socially, and politically. The new ASA "One-Gets-One" (membership, with rewards) and Emerging Scholars initiatives are excellent opportunities for this. Another way to do this would be to engage very intentionally with the student movements discussed above, and others as they emerge, possibly beginning with solidarity statements sent out to show that we are not only interested in the lives of Africans in Africa, but also the lives of African-descent people around the world. 
The ASA has already reached out to the ASAA about presenting a panel at the 2016 ASA meetings via teleconferencing. Could we-ASA, centers, and institutes-consider extending this to Black associations in Europe and the Caribbean, maybe through some joint panels? Similarly, the ASR could invite faculty and students of Black Studies and African American Studies programs to submit manuscripts. I would like to suggest here that the journal organize a special issue on the diverse Black Lives movements.

What would an African-centered approach to African Studies look like and what would it foretell? It would recognize the diverse experiences of African people while also recognizing our shared geopolitical history and contemporary realities. It would also emphasize the relationships among our realties_-so that the "othering" of Dominican immigrants in the U.S., for example, would be read as related to the global discourse on immigration, the continuing conflation of who Black and African people are and the problems we purportedly create. ${ }^{35}$

Within the academy on the continent, especially, we must actively seek to unsettle hegemonies-the silences, appropriations, and misrepresentations, especially between what many have referred to as the "metropole" and the "periphery." As Brenda Cooper and Robert Morrell (2014) and others have noted, the influence of certain knowers purports to benefit everyone, when in fact there is an inherent privileging. An African-centered knowledge agenda will develop tools and methodologies that are relevant to our context and enable "truer" pictures of our reality. Without necessarily discarding well-tested disciplinary and methodological canons, we must be fully aware that there is merit to the maxim, "African solutions for African problems." 36 The days of blindly (or greedily) absorbing every new theory "manufactured in Western laboratories [that] do not account for the complexities of African communities" (Kemedijo 2015) are over. How will we reassess which sources are legitimate? Whose authority and in what form? One of the projects we initiated at the UG Institute of African Studies, under the then occupant of the Kwame Nkrumah Chair, Jacob Gordon, was the building of a lab for oral histories within our archives.

The Shona respond to the greeting "How are you?" with the answer "I am well if you are well." May it be so for African and African Diaspora Studies as we share in our Black experience.

\section{Acknowledgments}

I would like to express my deepest appreciation to the editorial board of the African Studies Review and the ASA board of directors for selecting me as the 2015 ASR Distinguished Lecturer. The Women's Caucus and the Ghana Studies Association have been my homes within the ASA since I became a member in 1995, and I acknowledge their contributions to my critical appreciation of African Studies within area studies. I am grateful for the comments and questions I received after my talk, which I hope have improved this article. Finally, I acknowledge with gratitude the assistance 
of Edwin Adjei, currently a Ph.D. student at the Institute of African Studies, University of Ghana, for creating the database of all ASR issues from 1965 to 2015 that I refer to in this paper.

\section{References}

Adesanmi, Pius. 2011. You're Not a Country, Africa: A Personal History of the African Present. New York: Penguin.

Alexander, Shawn Leigh. 2015. W.E.B. Du Bois: An American Intellectual and Activist. London: Rowman and Littlefield.

Alkilimat, Abdul, et al. 2013. African American Studies 2013: A Nation Web-Based Survey. University of Illinois at Urbana Champaign Department of African American Studies. http:/ / afro.illinois.edu.

Attiah, Karen. 2015. "Woodrow Wilson Must Fall." The Washington Post, November 25. www.washingtonpost.com.

Badoe, Adwoa. 2012. "Unleashing the Story." Legon International Scholar Series (LISS) Speaker, November 12, Institute of African Studies, University of Ghana.

Challenor, Herschelle. 2002. "African Studies at Historically Black Colleges and Universities." African Issues 30 (2): 24-29.

Citi 97.3 FM. 2016. "University of Ghana to Establish Centre for European Studies." May 28. http:/ / citifmonline.com.

Clark, Amy. 2012. "People of African Descent in Europe.” A UKREN Briefing Paper. UK Race and Europe Network, June. http:/ / www.ukren.org.

Cooper, Brenda, and Robert Morell, eds. 2014. Africa-Centred Knowledges: Crossing Fields and Worlds. Oxford: James Currey.

Daily Mail. 2016. "Race Row over Chinese Detergent Advert Showing a Woman Shoving a Black Suitor into a Washing Machine and Then Smiling in Delight as He Emerges as an Asian Man.” May 26. http//www.dailymail.co.uk.

Dery, Mark. 1994. "Black to the Future: Interviews with Samuel R. Delany, Greg Tate, and Tricia Rose." In Flame Wars: The Discourse of Cyberculture, edited by Mark Dery, 179-222. Durham, N.C.: Duke University Press.

Du Bois, W.E.B. 1903. Souls of Black Folk. Chicago: A.C. McClurg.

Falola, Toyin, and Christian Jennings. 2002. Africanizing Knowledge: African Studies across the Disciplines. New Brunswick, N.J.: Transaction Publishers.

Gilbert, Sandra, and Susan Gubar. 2007. Norton Anthology of Literature by Women. New York: W.W. Norton and Company.

Gordon, Jacob, and Emmanuel Acheampong. 2016. Trends in African Studies. New York: Nova Science Publishers.

Guyer, Jane. 1996. African Studies in the United Studies: A Perspective. New Brunswick, N.J.: African Studies Association.

Herskovits, Melville. 1964. "The Development of Africanist Studies in Europe and America," In Proceedings of the First International Congress of Africanists, edited by Lalage Bown and Michael Crowder, 29-45. Evanston, Ill.: Northwestern University Press.

In His Own Home. 2015. Directed by Malini Johar Schueller. Indiepix Films. www. indipixfilms.com.

Kemedijo, Cilas. 2015. "The Virgin Fallacy: From the Famine Cotton Board to the Millennium Village Project." www.cihablog.com. 
Lukianoff, Greg, and Jonathan Haidt. 2015. "The Coddling of the American Mind.” The Atlantic, September. http://www.theatlantic.com.

Magubane, Bernard M. 1996. The Making of a Racist State: British Imperialism and the Union of South Africa, 1875-1910. Trenton, N.J.: Africa World Press.

Mbembe, Achille. 2002. "African Modes of Self-Writing." Public Culture 14 (1): 239-73.

Ndlovu-Gatsheni, Sabelo. 2014. "What Is Beyond Discourses of Alterity? Reflections on the Constitution of the Present and the Construction of African Subjectivity." In The Social Contract in Africa, edited by Sanya Osha, 111-30. Bramfontein: The Africa Institute of South Africa.

Nelson, Alondra, ed. 2002. Afrofuturism: A Special Issue of Social Text. Durham, N.C.: Duke University Press.

New African Magazine. 2013. "W.E.B. DuBois: The Father of Modern Pan-Africanism?” December 3. http://newafricanmagazine.com.

Nkrumah, Kwame. 1963. The African Genius. Speech Delivered at the Formal Opening of the Institute of African Studies, University of Ghana. Accra: Afram Publications.

Nyamnjoh, Francis B. 2016. \#RhodesMustFall: Nibbling at Resilient Colonialism in South Africa. Mankon, Cameroon: Langa Research and Publishing.

Olaniyan, Tejumola, and James H. Sweet. 2010. The African Diaspora and the Disciplines. Bloomington: Indiana University Press.

Parker, John, and Richard Reid, eds. 2013. The Oxford Handbook of Modern African History. Oxford: Oxford University Press.

Rotberg, Robert I. 1988. The Founder: Cecil Rhodes and the Pursuit of Power. Oxford: Oxford University Press.

Ruge, T. M. S. 2016. "Your White Savior Complex Is Detrimental to My Development." March 21. http://tmsruge.com.

Shujaa, Mwalimu, and Kenya J. Shujaa, eds. 2015. The SAGE Encyclopedia of African Cultural Heritage in North America. Thousand Oaks, Calif.: Sage Publications.

Soudien, Crain. 2014. "Foreword: The Power of Knowing." In Africa-Centred Knowledges: Crossing Fields and Worlds, edited by Brenda Cooper and Robert Morell, xv-xvi. Oxford: James Currey.

University World News. 2010. "AFRICA: Carnegie Grant for Next Generation Academics.” December 12. http:/ / www.universityworldnews.com.

Van Noorden, Richard, Brenda Maher, and Regina Nuzzo. 2014. "The Top 100 Papers." Nature 54 (7524). http:/ / www.nature.com.

Wong, Alia, and Adrienne Green. 2016. "Campus Politics: A Cheat Sheet." The Atlantic, April 4. http:/ / www.theatlantic.com.

Worland, Justin. 2015. "Why a Free Speech Fight Is Causing Protests at Yale." Time, November 10. http:// time.com.

Zeleza, Paul. T. 1997. Manufacturing African Studies and Crises. Dakar: CODESRIA Book Series.

\section{Notes}

1. I am fully aware that race is merely a social construct and I use the term "Black," with the capital letter, deliberately to signify shared belongingness in terms of culture, history, and identity. In their report on a 2013 survey of Black Studies, Abdul Alkalimat et al. pointed out that "Black was capitalized as it was the 
assumed name of a nationality," and added that "this practice continues to make sense given the reality of racism in the USA."

2. https://scholar.google.com/scholar?oi=bibs\&hl=en\&q=molecular+cloning.

3. The article, which describes an assay that determines the amount of protein found in a solution, had garnered more than 305,148 citations as of October 2014.

4. http://documentaryaddict.com/films/best.

5. www.youtube.com/watch?v=9bZkp7q19f0.

6. www.youtube.com/watch?v=rmfmdKOLzVI.

7. www.youtube.com/watch?v=GTUIlOudlHI.

8. www.youtube.com/watch?v=CQP-etYU1ps.

9. Some critics, like Manisha Desai, have referred to study abroad programs as an "industry" (panel, "Global Learning: Who Gets to Define It?", Winter meetings of Sociologists for Women and Society, Memphis, February 2014). And indeed, if one considers the secondary commerce generated through travel, hotels, immunization, orientation consultants, and the like, this term is apt. Many critiques of the humanitarianism industry address issues of the spectacularization of poverty, the Western voyeuristic gaze, cultural arrogance, and the so-called white savior complex that offers feel-good vibes but doesn't tackle the inequalities generated in the global North. See, for example, the illuminating blog posting of T. M. S. Ruge (2016) called "Your White Savior Complex Is Detrimental to My Development" and the "Critical Investigations into Humanitarianism" blog (www.cihablog.com).

10. www.vogue.com/946843/chimamanda-ngozi-adicihie-feminism-beyoncebook/.

11. Space limitations prevent a full discussion on "Afrofutures." Suffice it to say that the term, first coined by Mark Dery (1994), envisions Black futures particularly within a literary and cultural aesthetic. The concept has seen a resurgence in recent applications. I first encountered its current usage at a conference I attended in Bayreuth in 2014, attended by several literary, performance, and media scholars, including Alondra Nelson, who attended the same conference and has popularized its more recent use (see, e.g., Nelson 2002). The term "Afrofuturism," as used today, refers not only to notions of the cultural aesthetic, especially as experienced and expressed in the diaspora, but also to the continent, and the lived realities of Black bodies. Imagining futures by making associations with the past makes science fiction, for example, a popular medium for the expression of Afrofutures.

12. I have heard both Lungislie Ntsebeza, the current A. C. Jordan Chair at the Centre, and Mahmood Mamdani, the first occupant of the Chair, criticize the colonial study of the "other" at UCT in various forums, including at CODESRIA meetings.

13. View the full lecture at www.youtube.com/watch?v=HdmXDYZPz8g.

14. There is an impressive list of Black intellectuals who have paid attention to this subject of upliftment or advancement, including Anna Julia Cooper, Booker T. Washington (although he was Du Bois's intellectual rival), Fanny Jackson Coppin, Hugh Browne, Rose Butler Brown, Zora Neale Hurston, and Pauli Murray (whom I only recently learned about because a building at Yale University has been named after her in response to student demands for more recognition of the contributions of people of color).

15. See www2.ed.gov/about/offices/list/ope/iegps/title-six.html. 
16. See University World News (2010).

17. See The SAGE Encyclopedia of African Cultural Heritage in North America (Shujaa \& Shujaa 2015).

18. Their survey also captured other names that reflect the national and/or a diasporic reality-African American, Afro-American, Africana, pan-African, and others. The survey covered 1,777 U.S. colleges and universities that award bachelors, masters, and/or doctoral degrees, as identified by the Carnegie Foundation, and excluded programs that focus exclusively on Africa.

19. See www.africanstudies.org/images/PP-2012.pdf (ASA) and http://www.aegiseu.org/why-aegis (AEGIS).

20. www.as-aa.org/index.php/about-asaa.

21. See, e.g., the Daily Mail (2016) article about a racist Chinese laundry detergent.

22. I hope someone will carry out the much more elaborate process of producing a similar database of all papers presented at ASA meetings.

23. ASR did produce an issue in 1993 (vol. 36 [1]) titled "The Last Decade: A Content Analysis of the African Studies Review."

24. This effort is a first step, and further work will include an institutional analysis; for example, I am interested in looking at work that comes specifically out of HBCUs.

25. Sarah Baartman was the most famous of at least two Khoikhoi women who were exhibited as curiosities in nineteenth-century Europe under the now discredited name "Hottentot Venus." African feminists have used her story to draw attention to the double burdens of sexism and racism endured by black women.

26. I would like to thank Gretchen Bauer for bringing the Twitter exchange to my attention.

27. See Citi 93.7 FM (2016).

28. The University of Witwatersrand doctoral work of Leigh-Ann Naidoo, a leader of the "Rhodes Must Fall" campaign, focuses on the RMF movement, which she calls the "emergence of a new Black intellectual life" in South Africa. See http://mg.co.za/multimedia/2015-08-06-decolonising-institutions-leigh-annnaidoo. See also Francis Nyamnjoh's recent text “\#RhodesMustFall: Nibbling at Resilient Colonialism in South Africa" (2016), which provides an important chronology and analysis of the complexities of the South African movement.

29. See The Atlantic magazine's "cheat sheet" of some of the major campus protests (Wong \& Green 2016).

30. Woodrow Wilson's links to the Klan have recently received new attention as the extremely racist film, Birth of a Nation (originally called The Clansmen), by D. W. Griffith, which he hailed, has also received renewed attention following the release of a 2016 film by the same name by Nate Parker. Parker's film reclaims the title and is about a slave who becomes a leader.

31. Regina Titi Ofei, Georgetown University student (personal communication, April 2016).

32. See Worland (2015). The fraternity, Sigma Alpha Epsilon, had been banned from activities on campus and the party was held off campus. It had come under pressure in recent times at the University of Alabama for their chant, "You can hang from a tree, but will never sign with me, there will never be a nigger at SAE."

33. Erika Christakis was a deputy master of a residential college at Yale, and wife of Nicholas Christakis, the college's "master" (resident faculty member). The timing of her message was curious, given that it was made the week before Greg Lukianoff-co-author of an Atlantic magazine article titled "The Coddling of 
the American Mind" that received a great deal of attention-was due to speak at Yale. See Lukianoff and Haidt (2015). In 2016 Yale agreed to drop the title "master" following similar moves at Princeton and Harvard. The university did not, however, agree to change the name of Calhoun College, named after John C. Calhoun, an 1804 graduate of Yale College and an "intellectual forefather of the Confederacy who famously defended slavery as a 'positive good.'” See http:/ / news.yale.edu/2016/04/27/yale-retains-calhoun-college-s-nameselects-names-two-new-residential-colleges-and-change.

34. In the lecture from which this article is derived I proposed a merging of Black Studies and African Studies programs. This was foolhardy of me, and I want to thank Sandra Barnes for politely pointing this out after my talk. Beyond the practical politics that would make a merger unlikely, such a move would also not necessarily be helpful for learning purposes. What we need is for these programs to come out of their silos and talk to each other.

35. I would reject claims of "Afro-radicalism" or "nativism," as Mbembe (2002) does, in such endeavors.

36. The phrase (ASAP for short) has been used by the African Union to mean that Africa as a continent must endeavor to be full partners in addressing African problems. It has, however, been discredited by others as having no practical value, leading rather to the ignoring of the African situation by the international community and allowing bad leaders to use it as an excuse to continue to abuse their citizens. 


\title{
Appendix
}

\section{ASR Articles (1976-2010) on Pan-Africanism and the Diaspora}

\author{
1976 Jacob U. Gordon (University of Kansas). "Teaching the African Experience: \\ A Pan-African Approach.” ASR 19 (3). \\ 1977 L. Adele Jinadu (University of Lagos). "Some African Theorists of Culture and \\ Modernization: Fanon, Cabral and Some Others." ASR 20 (3). \\ 1979 Kenneth Hall (SUNY Oswego) and Byron Blake (CARICOM Secretariat, Guyana, \\ Barbados, Jamaica). "Emergence of the African-Caribbean-Pacific Group of States: \\ An Aspect of African and Caribbean International Cooperation.” ASR 22 (2). \\ 1992 Carlton E. Wilson (North Carolina Central University). "Racism and Private \\ Assistance: The Support of West Indian and African Missions in Liverpool, England, \\ During, the Interwar Years." ASR 35 (2). \\ 1994 Neil J. Savishinsky (New York University). "Rastafari in the Promised Land: The \\ Spread of a Jamaican Socioreligious Movement among the Youth of West Africa." \\ ASR 37 (3). \\ 1996 Edward O. Erhagbe (University of Benin). "African-Americans and the Defense of \\ African States Against European Imperial Conquest: Booker T. Washington's \\ Diplomatic Efforts to Guarantee Liberia's Independence 1907-1911.” ASR 39 (1). \\ 1999 Cortney Jung (Yale University). "Race Matters." ASR 42 (3). \\ 2007 Jacques Depelchin (Ota Benga Alliance for Peace, Healing, and Dignity). "Cuba \\ and the Recentering of African History." ASR 50 (1). \\ 2007 Rhoda E. Howard-Hassmann (Wilfrid Laurier University) and Anthony P. Lombardo \\ (University of Toronto). "Framing Reparation Claims: Differences Between African \\ and Jewish Social Movements for Reparations." ASR 50 (1). \\ 2009 Michelle C. Johnson (Bucknell University). "Death and the Left Hand: Islam, \\ Gender, and 'Proper' Mandinga Funerary Customs in Guinea-Bissau and Portugal." \\ ASR 52 (2). \\ 2010 Paul Tiyambe Zeleza (Loyola Marymount University). "African Diasporas: Toward \\ a Global History.” ASR 53 (1).
}

\section{“Africa's Diaspora: A Special Issue,” ASR 43 (1), 2000}

Judith Byfield (Dartmouth College). "Introduction: Rethinking the African Diaspora."

Tiffany Ruby Patterson (Binghamton University) and Robin D. G. Kelley (New York University). "Unfinished Migrations: Reflections on the African Diaspora and the Making of the Modern World."

Brent Hayes Edwards (Rutgers University), Cheryl Johnson-Odim (Columbia College), Agustin Lao-Montes (University of Massachusetts), Michael O. West (University of North Carolina), Tiffany Ruby Patterson (Binghamton University), and Robin D. G. Kelley (New York University). "Unfinished Migrations": Commentary and Response."

Hakim Adi (Middlesex University). "Pan-Africanism and West Africa Nationals in Britain.” 
Edward A. Alpers (University of California, Los Angeles). "Recollecting Africa: Diasporic Memory in the Indian Ocean World."

Herman L. Bennett (Rutgers University). "The Subject in the Plot: National Boundaries and the 'History' of the Black Atlantic."

Kim D. Butler (Rutgers University). "From Black History to Diasporan History: Brazilian Abolition in Afro-Atlantic Context."

Amanda D. Kemp (Dickinson College) and Robert Trent (Howard University). "Poking Holes in the Sky": Professor James Thaele, American Negroes, and Modernity in 1920s Segregationist South Africa."

Ivor Miller (Schomburg Center for Research in Black Culture). "A Secret Society Goes Public: The Relationship Between Abakua and Cuban Popular Culture.” Vijay Prashad (Trinity College). "Afro-Dalits of the Earth, Unite!" 